\title{
Kinerja Tutor Terhadap Kepuasan Mahasiswa Pada Tutorial Webinar (TUWEB) PGSD UPBJJ-UT Makassar Di Kabupaten Wajo
}

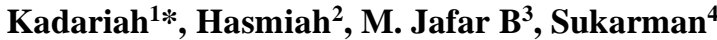 \\ 1,2,3,4 Manajemen Pendidikan Universitas Terbuka, Makassar \\ ${ }^{1}$ Email: kadariah@ecampus.ut.ac.id; ${ }^{2}$ Email: hasmiah@ecampus.ut.ac.id; \\ ${ }^{3}$ Email: m.jafar.b@ecampus.ut.ac.id; ${ }^{4}$ Email: sukarman@ecampus.ut.ac.id; \\ *Corresponding author
}

(Received: 24 Desember 2020; Accepted: 25 Januari 2021; Published: 30 Januari 2021)

\begin{abstract}
This study aims to explain the correlation between tutor performance and the level of student satisfaction in the webinar tutorial (Tuweb). This study uses two approaches, namely quantitative and qualitative approaches. Data were analyzed using simple linear regression analysis. The sampling technique was simple random sampling of 40 people. The regression coefficient value is 0.144 , this means that if the tutor's performance has increased by one unit, the level of student satisfaction in the UPBJJ-UT Makassar webinar (Tuweb) tutorial in Wajo Regency increases by 0.144 units. The determination coefficient test (KD) or the $\mathrm{R} 2$ test is 0.598 or $59.8 \%$, which means that the effect of tutor performance on student satisfaction on webinar tutorials (Tuweb) is 59.8\%. The results of the analysis and processing of research data show that there is a positive and significant influence between tutor performance on student satisfaction in the PGSD UPBJJ-UT Makassar webinar tutorial in Wajo Regency. This means that it is very supportive of the learning conditions during the Covid-19 pandemic, which really requires all sectors and fields, especially in the field of education, which demands to continue to innovate to promote online or online learning systems.
\end{abstract}

Keywords: Tutor Performance; Webinar Tutorial (Tuweb); and Student Satisfaction

\begin{abstract}
Abstrak: Penelitian ini bertujuan untuk menjelaskan korelasi antar kinerja tutor terhadap tingkat kepuasan mahasiswa pada tutorial webinar (Tuweb). Penelitian ini menggunakan dua pendekatan yaitu pendekatan kuantitatif dan kualitatif. Data dianalisis dengan menggunakan analisis regresi linear sederhana. Teknik pengambilan sample dengan Simple Random Sampling sebanyak 40 orang. Nilai koefisien regresi sebesar 0,144, hal ini berarti bahwa jika kinerja tutor mengalami peningkatan sebesar satu satuan maka tingkat kepuasan mahasiswa pada tutorial webinar (Tuweb) UPBJJ-UT Makassar di Kabupaten Wajo meningkat sebesar 0,144 satuan. Uji Koefisien Determinasi (KD) atau uji $\mathrm{R}^{2}$ sebesar 0.598 atau 59,8\% yang artinya pengaruh kinerja tutor terhadap kepuasan mahasiswa pada tutorial webinar (Tuweb) adalah sebesar 59,8\%. Hasil analisis dan pengolahan data penelitian diketahui bahwa ada pengaruh positif dan signifikan antara kinerja tutor terhadap kepuasan mahasiswa pada tutorial webinar (Tuweb) PGSD UPBJJUT Makassar di Kabupaten Wajo. Hal ini berarti bahwa sangat mendukung dengan kondisi pembelajaran di masa pandemic Covid-19 ini yang sangat mengharuskan semua sector dan bidang terutama dalam bidang pendidikan yang menuntut untuk terus berinovasi untuk menggalakkan system pembelajaran daring atau online.
\end{abstract}

Kata Kunci: Kinerja Tutor; Tutorial Webinar (Tuweb); dan Kepuasan Mahasiswa

\section{PENDAHULUAN}

Sistem Pendidikan Tinggi Terbuka dan Jarak Jauh (PTTJJ) adalah sistem pendidikan yang diterapkan oleh Universitas Terbuka (UT). Dan UT adalah Perguruan Tinggi negeri ke 45 di
Indonesia yang diresmikan pada tanggal 4 September 1984, berdasarkan Keputusan Presiden RI Nomor 41 tahuan 1984. UT merupakan satu-satunya perguruan tinggi negeri di Indonesia yang sepenuhnya menerapkan 
Pendidikan Tinggi Terbuka dan Jarak Jauh (PTTJJ). Istilah pendidikan terbuka mengandung arti bahwa UT menyelenggarakan pendidikannya tanpa melakukan tanpa seleksi masuk, tanpa batasan usia, tanpa batasan lokasi geografis, tidak mempersyaratkan latar belakang pendidikan tertentu, tanpa batasan tahun ijazah SLTA, tanpa batasan masa studi, sedangkan istilah sistem pendidikan jarak jauh mengandung arti bahwa pembelajaran di UT tidak dilakukan secara On line ,melainkan menggunakan media pembelajaran, baik cetak maupun non-cetak.

Tujuan pendirian UT adalah untuk: (1) memberikan kesempatan yang luas bagi warga negara Indonesia dan warga negara asing di manapun tempat tinggalnya, untuk memperoleh pendidikan tinggi, (2) memberikan layanan pendidikan tinggi bagi mereka, yang karena bekerja atau karena alasan lain, tidak dapat melanjutkan pendidikannya di perguruan tinggi On line, dan (3) mengembangkan program pendidikan akademik dan profesional sesuai dengan kebutuhan nyata pembangunan yang belum banyak dikembangkan oleh perguruan tinggi lain (Katalog Sistem Penyelenggaraan Program Non Pendas UT, 2015). Karakteristik UT dalam menyelenggarakan pembelajarannya on line lebih menekankan pembelajaran yang terbuka dan jarak jauh. Istilah jarak jauh ini mempunyai arti bahwa pembelajaran tidak dilakukan secara On line, melainkan dengan menggunakan media, baik media cetak (modul) maupun media non cetak maupun non-cetak (audio/video, komputer/Internet, siaran radio dan televisi). Makna terbuka adalah tidak ada pembatasan usia, tahun ijazah, masa belajar, waktu registrasi, frekuensi mengikuti ujian, dan sebagainya.

Perkembangan ilmu pengetahuan dan teknologi yang demikian cepat menuntut kita untuk terus meningkatkan potensi sumber daya manusia untuk menunjang produktivitas. Kemajuan tersebut berdampak pada kegiatan pengajaran yang bervariasi, sehingga pembelajaran lebih menyenangkan ((Ramli et al., 2018). Namun, keterbatasan tempat dan waktu menjadi kendala utama bagi banyak orang dalam mengembangkan diri dan meningkatkan karir. Universitas Terbuka (UT) adalah Perguruan Tinggi Negeri ke 45 di Indonesia yang menerapkan sistem belajar terbuka dan jarak jauh. Sistem belajar ini terbukti efektif untuk meningkatkan daya jangkau dan pemerataan kesempatan pendidikan tinggi yang berkualitas bagi semua warga negara Indonesia.
Termasuk mereka yang tinggal di daerahdaerah terpencil baik di seluruh nusantara maupun di berbagai belahan dunia lain. Dalam hal pembelajaran, Universitas Terbuka juga memiliki bantuan belajar Tutorial Tatap Muka (TTM). Pembelajaran tatap muka di UT lebih mengedepankan forum diskusi di kelas antara mahasiswa dengan tutor.Selain bantuan belajar Tutorial Tatap Muka, UT memiliki bantuan belajar Tutorial Online (TUWEB) dan Tutorial Webinar (TUWEB). Layanan ini diselenggarakan UT dan diikuti oleh mahasiswa melalui jaringan internet yang bertujuan mengoptimalkan pemanfaatan jaringan internet untuk memberikan layanan bantuan belajar kepada mahasiswa guna melaksanakan proses pembelajaran jarak jauh yang di desain lebih komunikatif dan interaktif.

Khusus untuk Tutorial Webinar, penggunaan aplikasi Microsoft Teams sangat membantu komunikasi mahasiswa dengan para tutor dalam menjalani perkuliahan yang terkendala dengan pembatasan berkumpul secara bersama-sama di satu tempat.

Pergeseran kegiatan tutorial dalam masa Pandemi Covid-19 dari Tutorial Tatap Muka menjadi Tutorial Webinar tidak menjadi halangan mahasiswa UT dalam menempuh pendidikan. Universitas Terbuka hadir menyediakan bantuan Pembelajaran Online (Daring) bagi Perguruan Tinggi yang memerlukan platform untuk melakukan pembelajaran di luar kampus sebagai upaya mencegah penyebaran COVID-19.

Bantuan pembelajaran disediakan melalui platform Learning Management System (LMS) di alamat https://lms.ut.ac.id dengan pemberian layanan Ruang Baca Virtual (RBV) yang menyediakan bahan ajar untuk 1.350 mata kuliah guna membantu PTN/PTS yang ingin melaksanakan online learning. Sehingga tidak ada lagi mahasiswa yang tidak bisa belajar dari rumah seiring dengan peraturan presiden yang menerapkan study from home

Sementara itu berdasarkan capaian Renstra dan Renop 2010 sd 2021 (Renstra 20102021) pada sasaran 3, dimana salah satu layanannya yaitu layanan tutorial sudah tersedia dalam berbagai modus dan dapat diakses oleh mahasiswa serta perlu dipertahankan dan ditingkatkan kualitas seluruh layanan tutorial yang tersedia, maka PGSD FKIP memandang perlu untuk dilakukan evaluasi tentang proses pembelajaran tersebut. Hal ini penting untuk mengetahui sejauh mana kualitas layanan proses 
pembelajaran yang selama ini sudah berjalan. Kajian tentang tingkat kepuasan mahasiswa terhadapa layanan dalam proses pembelajaran di UT tersebut perlu dilakukan dengan harapan dapat meningkatkan mutu layanan dalam proses pembelajaran di masa depan, yang pada gilirannya dapat meningkatkan indeks prestasi mahasiswa PGSD UPBJJ-UT Pokja Makassar.

Fakta ketika penulis melakukan kegiatan monitoring mahasiswa sering mengeluhkan tentang kurang optimalnya layanan tutorial, sebagai wadah pelayanan dan bimbingan belajar kepada mahasiswa untuk membantu mereka mencapai hasil belajar secara optimal melalui On line . Transfer ilmu pengetahuan yang dilakukan melalui pendampingan tutor yang berasal dari para guru, dosen perguruan tinggi negeri atau swasta didaerah kurang maksimal. Keluhan dari mahasiswa tentang sulitnya memahami matakuliah yang ditutorialkan, kegiatan tutorial dilakukan tidak sesuai dengan jadwal, jumlah pertemuan yang dilaksanakan tidak maksimal, nilai ujian akhir semester yang dicapai kurang memuaskan, dan banyak lagi masalah lainnya sebagai bentuk gambaran pelayanan kurang optimal. Keluhan yang sering terdengar ini merupakan ekspresi dari ketidakpuasan dari mahasiswa.

Hal yang menarik walaupun mahasiswa menyadari ketidakpuasan yang didapat dalam kualitas pengajaran dari tutor dan mahasiswa terus mengikuti kegiatan tutorial, tetapi mereka enggan menyampaikan perasaannya baik dalam bentuk kritik atau sarannya terhadap para tutor yang mengajar. Dalam capaian kepuasan nampaknya mahasiswa memang berusaha untuk menerima pengajaran dan nilai yang diperoleh, akan tetapi tetap saja ketidakpuasan masih melekat didalam pemberian proses belajarnya. Oleh karena itu tantangan yang dihadapi saat ini adalah bagaimana kita mengedepankan pelayanan untuk merespon ketidakpuasan mahasiswa sebagai peserta didik. Jika disadari dengan seksama mahasiswa tidak hanya diberikan ilmu saja, tetapi bagaimana tingkat kepuasannya dapat terpenuhi, hal inilah yang perlu diketahui tutor yang mengajar di PGSD UPBJJ-UT Pokja Makassar. Dalam kaitannya dengan layanan tutorial On line , satu hal yang dapat mempengaruhi kepuasan mahasiswa sebagai pengguna jasa pendidikan dari universitas adalah kinerja tutor.

Kemampuan tutor dalam melaksanakan tutorial merupakan salah satu faktor yang berpengaruh terhadap keberhasilan pembelajaran tutorial. Untuk dapat melaksanakan tutorial yang efektif, tutor harus memiliki penguasaan bidang ilmu (mata kuliah) yang ditutorialkan, menguasai kemampuan merancang dan melaksanakan pembelajaran yang mendidik, serta memahami karakter mahasiswa (2006, Wardani dan Juleha). Kinerja seorang dosen merupakan suatu perilaku atau respons yang memberikan hasil yang mengacu kepada apa yang ia kerjakan ketika ia menghadapi suatu tugas. Kinerja dosen ini menyangkut semua aktivitas yang dialami oleh seorang dosen dalam mencapai suatu tujuan atau hasil.

Kinerja seorang dosen pada dasarnya mengarah pada perilaku seorang dosen dalam pekerjaannya. Hal-hal tersebut akan tampak dalam perilaku dosen dalam proses pembelajaran dan interaksi antara dosen dan mahasiswa. (Mukhtar, 2003). Kinerja dosen dalam berbagai ketrampilan atau berprilaku adalah keterampilan mengajar, menilai, membimbing, menggunakan alat bantu pengajaran, berkomunikasi dengan mahasiswa, keterampilan menumbuhkan semangat belajar para mahasiswa, keterampilan menyusun persiapan atau perencanaan mengajar, keterampilan melaksanakan pembelajaran (Sudjana, 2002).

Jika dikaitkan dengan kinerja tutor, maka kepuasan mahasiswa terhadap kinerja tutor di UPBJJ-UT Pokja Makassar yang dimaksud dalam penelitian ini adalah suatu respon afektif atau emosional mahasiswa terhadap unjuk kerja yang ditampilkan tutor dalam melaksanakan tugasnya pada proses kegiatan tutorial dengan indikasi yaitu; 1) Penguasaan tutor terhadap materi tutorial, 3) cara tutor menyampaikan materi tutorial, 4) Cara tutor berkomunikasi dalam berinteraksi dengan mahasiswa, 5) disiplin kerja tutor dalam melaksanakan tugasnya, $\quad 6$ ) cara tutor menilai tugas yang diberikan kepada mahasiswa.

\section{METODE PENELITIAN}

Penelitian ini menggunakan pendekatan kuantitatif dan kualitatif. Penelitian ini dirancang untuk dilaksanakan dalam dua tahap. Tahap pertama dengan metode survey, dan tahap ke 2 yaitu dengan wawancara mendalam dan FGD dengan menggunakan perhitungan matematis dan angka-angka statistik. Sifat dan jenis dalam penelitian ini adalah ex-post facto, merupakan penelitian dimana variabel-variabel bebas telah terjadi ketika peneliti mulai dengan pengamatan variabel terikat dalam suatu penelitian. 


$$
\text { PNS }=\frac{\text { Jumlah perolehan skor }}{\text { Skor Maksimum }} \times 100
$$
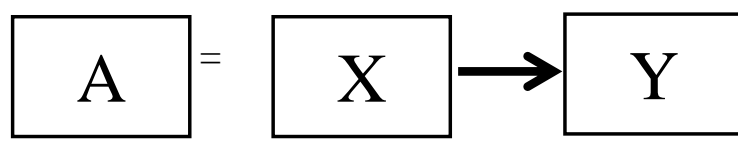

Keterangan:

A $=$ Sampel kelas acak

$\mathrm{X}=$ Kinerja tutor dalam tutorial

$\mathrm{Y}=$ Kepuasan Mahasiswa

$\longrightarrow=$ Hubungan antara $\mathrm{X}$ dengan $\mathrm{Y}$

Populasi dalam penelitian ini adalah seluruh mahasiswa PGSD UPBJJ-UT Pokja Makassar di Kabupaten Wajo kemudian ditentukan sampel secara acak 40 orang. Teknik pengumpulan data yang digunakan dalam penelitian ini adalah Kuesioner. Bentuk kuesioner (angket) yang digunakan dalam penelitian ini berupa pernyataan berskala gradasi yakni: sangat puas (SP), puas (P), cukup puas (CP), kurang puas (KP) dan sangat kurang puas (SKP), dan jenis angket tertutup yaitu suatu angket yang terdiri dari pernyataan dan alternatif jawaban telah ditentukan sehingga responden tinggal memilih jawaban sesuai yang diinginkan.

Pengolahan data primer dengan metode coding, editing, tabulating, serta klasifikasi data. Untuk mengetahui pengaruh kinerja tutor dalam tutorial webinar terhadap kepuasan mahasiswa berdasarkan aspek tangible (sarana dan prasarana pendidikan), aspek reability (Kehandalan dosen), Aspek responsiveness (sikap tanggap), Aspek Assurance (Perlakuan pada mahasiswa), aspek empathy (pemahaman terhadap kepentingan mahasiswa). Selanjutanya data dianalisis dengan menggunakan analisis regresi liniear sederhana untuk meramalkan atau memprediksi pengaruh dari data (variabel bebas) terhadap data yang lain (variable tak bebas) dengan program aplikasi SPSS versi 20 for windows.

\section{HASIL DAN PEMBAHASAN}

Untuk menganalisis jawaban responden, diukur menggunakan pernyataan dengan skala likert. Selanjutnya untuk menetapkan peringkat dalam setiap variabel penelitian dapat dilihat dari perbandingan antara skor aktual dengan skor ideal dengan rumus yang dicantumkan dalam Narimawati (2007:84) sebagai berikut:
Keterangan:

- PNS: Perolehan Nilai Siswa

- Skor aktual adalah skor jawaban yang diperoleh dari seluruh responden atas kuesioner yang telah diajukan

- Skor ideal adalah skor maksimum atau skor tertinggi yang mungkin diperoleh jika semua responden memilih jawaban dengan skor tertinggi.

Adapun kriteria interpretasi skor menurut Riduwan dalam Nureni (2011:39) adalah sebagai berikut:
1) Angka 0\%-20\%= sangat tidak setuju
2) Angka $21 \%-40 \%=$ tidak setuju
3) Angka $41 \%-60 \%$ = cukup setuju
4) Angka $61 \%-80 \%=$ setuju
5) Angka $81 \%-100 \%=$ sangat setuju

Hasil jawaban responden atas pernyataan yang diberikan berdasarkan indikator yang dianalisis sebaga berikut:

Dari aspek indikator kemudahan pengoperasian tutorial webinar diperoleh $33 \%$ mahasiswa sangat setuju dan 53\% setuju artinya tutorial webinermudah dioperasikan, kemudian indikator tutorial webinar menyediakan materi yang lengkap dan terperinci $40 \%$ menyatakan setuju dan $60 \%$ menyatakan setuju artinya materi yang tersedia di tutorial webinersudah cukup lengkap dan terperinci.

Dari aspek indikator tutorial webinar membuat aktif mahasiswa diperoleh $47 \%$ mahasiswa sangat setuju dan $47 \%$ setuju artinya mahasiswa bisa lebih aktif, kemudian indikator tutorial webinermemiliki inovasi yang menyenangkan, sebanyak $73 \%$ menyatakan setuju dan $27 \%$ menyatakan setuju artinya tutorial webinar menyenangkan, dilanjutkan indikator tutorial webinersangat nyaman dibandingkan pembelajaran biasa diperoleh $40 \%$ sangat setuju dan 53\% setuju artinya mahasiswa lebih nyaman dengan tutorial webinar ini. Dari rata-rata tingkat kepuasan mahasiswa UT dalam pembelajaran online ini lebih dari $70 \%$ mahasiswa pada tingkat setuju dan puas atas pelayanan tersebut.

Mengetahui tingkat keberhasilan hasil belajar mahasiswa dalam menggunakan tutorial webinerDalam mencapai tujuan yang ketiga yaitu membuat tes online untuk mengetahui tingkat keberhasilan hasil belajar mahasiswa 
dalam menggunakan tutorial webinar pada PGSD UPBJJ-UT Makassar di Kabupaten Wajo dijelaskan sebagai berikut:

1) Membuat soal online sebanyak 10 soal di bagian

2) Menggunakan aplikasi ProProfs dalam membuat tes online

3) tes online sudah jadi kemudian dilinkan dengan blog eemkurniasihut.blogspot.com

4) Mahasiswa dapat mengerjakan online tersebut dimana saja dan kapan saja.

5) Hasil rekapitulasi tes online langsung bisa diketahui progress and reportnya

6) Kemudian setiap mahasiswa dapat mendownload sertifikat hasil tes online pada waktu bersamaan.

Berikut ini adalah hasil produk tes online sebagai berikut:

Kemampuan Mahasiswa Menggunakan Internet bervariasi dari kategori rendah, sedang, dan tinggi. Kemampuan mahasiswa PGSD UPBJJ-UT Makassar di Kabupaten Wajo dalam menggunakan internet paling banyak pada tingkat sedang $(66,7 \%)$, sedangkan mahasiswa lainnya paling banyak $(46,7 \%)$ berkemampuan internet rendah. Hal ini disebabkan oleh letak kabupaten Wajo yang jauh dari ibu kota sehingga jauh dari jangkauan jaringan internet. Hal ini berbeda dengan suasana di Kota Makassar yang sudah terbiasa dengan internet, sehingga kondisi ini juga mendukung mahasiswa PGSD UPBJJ-UT Makassar di Kabupaten Wajo.

Kemampuan menggunkan internet mahasiswa PGSD UPBJJ-UT Makassar di Kabupaten Wajo berdasarkan kategori rendah ada sebanyak 9 orang atau sebesar 23,8 persen, pada kategori sedang sebanyak 27 orang atau sebesar 66,7 persen, dan pada kategori tinggi sebanyak 4 orang atau sebesar 9,5 persen. Kategori tersebut dimana pada tingkat rendah (mahasiswa tidak pernah menggunakan internet di luar tuweb), kategori sedang artinya mahasiswa jarang menggunakan internet di luar tuweb, dan pada kategori tinggi artinya mahasiswa sering menggunakan internet di luar tuweb.

Materi Inisiasi Tuweb Persepsi mahasiswa terhadap materi inisiasi Tuweb dikelompokkan menjadi persepsi terhadap tingkat keterbacaan materi inisiasi, kesesuaian materi inisiasi dengan modul, dan sistematika materi inisiasi. Selengkapnya persepsi mahasiswa terhadap tingkat keterbacaan materi inisiasi dapat dijelaskan bahwa persepsi mahasiswa terhadap tingkat keterbacaan materi inisiasi tergolong tinggi, karena mahasiswa PGSD UPBJJ-UT Makassar di Kabupaten Wajo sebanyak 90,5\% menganggap mudah memahami materi inisiasi dan persentase tersebut merupakan suatu hal yang menggembirakan karena materi inisiasi dapat digunakan oleh mahasiswa untuk membantu memahami materi yang. Selain itu, materi inisiasi juga dapat digunakan untuk menambah pengetahuan terutama untuk materi yang tidak ada pada mata pelajaran di PGSD UPBJJ-UT Makassar di Kabupaten Wajo.

Persepsi mahasiswa terhadap kesesuaian materi inisiasi dengan modul pada mahasiswa PGSD UPBJJ-UT Makassar di Kabupaten Wajo $(85,7 \%)$ mereka menganggap materi inisiasi sudah sesuai dengan modul. Artinya, materi inisiasi yang dibuat oleh tutor tidak menyimpang dari materi yang ada pada modul. Kesesuaian ini penting untuk membangun pemahaman mahasiswa agar menghasilkan pemahaman yang utuh terhadap suatu materi perkuliahan. Selanjutnya, persepsi mahasiswa terhadap sususan materi inisiasi dimana mahasiswa mempunyai persepsi yang baik terhadap susunan materi inisiasi dan menganggap materi inisiasi sudah tersusun secara sistematis. Hal ini bermakna setiap materi inisiasi sudah tersusun secara runut dari pendahuluan, isi materi, dan kesimpulan. Urutan ini penting untuk menuntun logika mahasiswa dalam memahami materi tuweb. Susunan materi inisiasi yang sudah sistematis menurut mahasiswa, diharapkan dapat mempermudah mahasiswa dalam mempelajari materi inisiasi dan modul.

Untuk melatih dan meningkatkan mahasiswa dalam kemampuan berdiskusi, di dalam Tuweb disediakan forum diskusi. Forum ini dapat digunakan untuk mahasiswa dalam menuangkan gagasan, jawaban pertanyaan, ataupun pertanyaan materi kuliah kepada tutor. Melalui forum ini pula tutor dapat menilai tingkat keaktifan mahasiswa dalam tuweb. Oleh karena itu, pertanyaan diskusi dalam Tuweb harus dibuat semenarik mungkin sehingga mahasiswa tergugah untuk menjawab pertanyaan tersebut.

Menurut persepsi mahasiswa $86,7 \%$ pertanyaan dalam Tuweb mudah dipahami. Artinya, persepsi mahasiswa terhadap pertanyaan diskusi tergolong tinggi karena sebagian besar mahasiswa merasa mudah memahami pertanyaan diskusi. Hal ini berdampak pada tingkat keaktifan mahasiswa dalam menjawab pertanyaan tuweb. Meskipun sebanyak $86,7 \%$ mahasiswa menganggap bahwa 
pertanyaan diskusi mudah dipahami, tetapi yang sering menjawab pertanyaan Tuweb hanya $61,9 \%$ saja. Hal ini disebabkan mahasiswa sering kesulitan dalam membuka jaringan internet. Selain itu, kemampuan mahasiswa menggunakan internet juga turut mempengaruhi jumlah mahasiswa yang menjawab pertanyaan tuweb. Menurut Susanti (2007), kemampuan mahasiswa S2 menggunakan internet dapat ditingkatkan melalui program OSMB (orientasi mahasiswa baru). Pada program tersebut, dapat diperdalam materi tentang mengakses internet, mengakses inisiasi, pertanyaan diskusi, dan tugas tuweb Ketertarikan mahasiswa dalam menjawab pertanyaan diskusi Tuweb diduga berkaitan dengan kesesuaian pertanyaan diskusi dengan materi inisiasi. Persepsi mahasiswa terhadap kesesuaian pertanyaan dengan materi inisiasi selengkapnya dapat dijelaskan bahwa mahasiswa $85,7 \%$ menganggap bahwa pertanyaan Tuweb sesuai dengan materi inisiasi. Kesesuaian ini diharapkan dapat mendukung keaktifan mahasiswa dalam menjawab materi pertanyaan tuweb, karena menurut Suparman (2004) sistem belajar di UT adalah sistem belajar mandiri sehingga keaktifan mahasiswa dalam menjawab pertanyaan Tuweb sangat membantu mahasiswa dalam memahami materi perkuliahan. Keaktifan mahasiswa dalam menjawab pertanyaan Tuweb dapat dirangsang dengan pertanyaan Tuweb yang mengarahkan mahasiswa untuk membaca modul dan memahaminya. Ketertarikan mahasiswa menjawab pertanyaan Tuweb diduga juga berkaitan dengan susunan kalimat pertanyaan dalam tuweb.

Persepsi mahasiswa terhadap susunan pertanyaan Tuweb selengkapnya dijelaskan bahwa mahasiswa $86,7 \%$ menganggap bahwa susunan pertanyaan Tuweb sistematis. Pertanyaan Tuweb yang sistematis artinya adalah pertanyaan Tuweb yang disusun dari yang paling mudah meningkat ke pertanyaan yang sulit. Implikasi dari temuan ini adalah perlu diadakan tinjauan ulang terhadap susunan pertanyaan tuweb, khususnya untuk UPBJJ-UT Jakarta karena 52,4\% yang menjawab sistematis, berarti ada 47,6\% yang menganggap bahwa pertanyaan Tuweb tidak sistematis. Tugas Tuweb Selain materi inisiasi dan pertanyaan, Tuweb juga memuat tugas yang harus dikerjakan oleh mahasiswa dan diserahkan kepada tutor tatap muka. Menurut Universitas Terbuka (2004), tugas merupakan salah satu jenis evaluasi yang dilakukan pada tutorial online.
Penilaian tugas Tuweb merupakan salah satu alat evaluasi hasil belajar (EHB) untuk menilai penguasaan mahasiswa terhadap materi mata kuliah dan kemampuan menerapkan pemahaman yang dimilikinya pada konteks yang relevan. Tugas Tuweb yang harus dikerjakan oleh mahasiswa ada tiga tugas. Mahasiswa harus memahami tugas dengan baik, agar dapat dikerjakan secara baik dan tepat oleh mahasiswa. Pengerjaan tugas Tuweb dengan baik dan benar akan membantu mahasiswa untuk meningkatkan nilai partisipasi tuweb, yang akhirnya akan berkontribusi kepada nilai akhir mata kuliah. Persepsi mahasiswa terhadap tingkat keterbacaan tugas tuweb.

Tingkat keterbacaan tugas Tuweb dianggap mudah oleh mahasiswa 93,3\%. Persentase tersebut menunjukkan bahwa mahasiswa tidak mengalami kesulitan dalam memahami tugas tuweb. Hal ini adalah suatu hal yang baik karena dengan tidak ada kesulitan dalam memahami tugas tuweb, mahasiswa diharapkan dapat mengerjakan tugas dengan baik dan tepat waktu. Pengerjaan tugas Tuweb dapat melatih mahasiswa dalam membuat karya ilmiah dan dapat membantu meningkatkan nilai akhir mahasiswa.

Persepsi mahasiswa terhadap kesesuaian tugas dengan materi inisiasi dapat dijelaskan bahwa kesesuaian tugas dengan materi inisiasi juga ditanggapi baik oleh mahasiswa 90,5\%. Artinya adalah materi tugas tutun tidak menyimpang dengan modul yang berisi materi perkuliahan. Dengan demikian, tugas Tuweb dapat memberikan pendalaman materi kepada mahasiswa, dan diharapkan dapat melatih mahasiswa dalam menghadapi ujian.

Susunan kalimat tugas juga ditanggapi baik oleh mahasiswa, dibuktikan dengan mahasiswa 93,3\% menganggap bahwa susunan kalimat tugas sudah sistematis. Artinya, susunan kalimat tugas sudah runut, dari tugas yang sifatnya mudah menuju ke tingkatan yang sulit. Persepsi mahasiswa terhadap susuan kalimat tugas selengkapnya dapat dijelaskan bahwa setelah pengerjaan tugas, mahasiswa diharapkan dapat menulis karya ilmiah untuk kepentingan proses belajar mengajar, maupun kepentingan dunia kerja. Kemampuan menulis karya ilmiah ini adalah kompetensi yang harus dimiliki oleh mahasiswa pendidikan tinggi jarak jauh yang menerapkan sistem belajar mandiri. Dengan mengerjakan tugas tuweb, mahasiswa jadi belajar menulis ide, dengan demikian mahasiswa 
akan membuka referensi yang diperlukan, sehingga proses belajar akan terjadi.

Berdasarkan penyajian data maka selanjutnya dilakukan analisis dengan menggunakan analisis regresi linear sederahan dengan maksud untuk mengetahui pengaruh antara variabel bebas yaitu kinerja tutorial terhadap variabel terikat yaitu kepuasan mahasiswa. Analisis regresi juga memungkinkan pengujian hubungan sebab akibat antarvariabel. Dalam analisis regresi ada beberapa proses yang dilakukan antara lain transformasi data, uji korelasi, dan uji hipotesis yang terdiri dari uji simultan (uji F), uji Koefisien Determinasi (uji $\mathrm{R}^{2}$ atau KD), serta uji parsial (uji t). Data yang didapat dari hasil kuesioner yang menggunakan skala likert adalah data ordinal yang kemudian diolah menjadi data berskala interval dengan menggunakan program SPSS Version 20 for Windows.

Data yang telah ditransformasi menggunakan diolah oleh program SPSS Version 20 for Windows hingga didapatkan hasil uji korelasi antar variabel dengan hasil; variabel kemudahan penggunaan $\left(\mathrm{X}_{1}\right)$ memiliki hubungan yang sedang terhadap variabel kepuasan mahasiswa (Y), dibuktikan dengan nilai korelasi Pearson sebesar $+0,308$. Maka dapat disimpulkan bahwa dalam penelitian ini mempunyai hubungan atau korelasi signifikan. Berdasarkan hasil analisis regresi sederhana yang dilakukan diperoleh persamaan sebagai berikut:

$$
\mathrm{Y}=\mathbf{0 , 2 1 1}+\mathbf{0 , 1 4 4} \mathrm{X}
$$

Berdasarkan model persamaan yang diperoleh, diketahui bahwa nilai konstanta sebesar 0,211, hal ini berarti bahwa jika kinerja tutor bernilai nol, maka variabel kepuasan mahasiswa pada tutorial webinar UPBJJ-UT Makassar Pada di Kabupaten Wajo meningkat sebesar 0,211 satuan.

Nilai koefisien regresi sebesar 0,144 , hal ini berarti bahwa jika kinerja tutor rmengalami peningkatan sebesar satu satuan maka tingkat kepuasan mahasiswa pada tutorial webinar UPBJJ-UT Makassar di Kabupaten Wajo meningkat sebesar 0,144 satuan.

Uji selanjutnya adalah uji Koefisien Determinasi (KD) atau uji R2 yaitu untuk mengetahui seberapa besar pengaruh variabel kinerja tutorial terhadap kepuasan mahasiswa. Berikut ini hasil perhitungan uji KD atau uji R2 dengan menggunakan program SPSS Version 20 for Windows didapatkan nilai Koefisien Determinasi atau $\mathrm{R}^{2}$ sebesar 0.598 atau $59,8 \%$ yang artinya pengaruh kinerja tutorial terhadap kepuasan mahasiswa adalah sebesar 59,8\%. Sedangkan sisanya $40,2 \%$ dipengaruhi faktor lain yang tidak dibahas dalam penelitian ini.

Selanjutnya dilakukan penghitungan uji t untuk mengetahui signifikansi dan untuk menguji secara parsial masing-masing variabel bebas kinerja tutor terhadap variabel terikat kepuasan mahasiswa. Dengan tingkat kesalahan (a) $5 \%$ atau 0.05 dan $\mathrm{dk}=\mathrm{n}-\mathrm{k}=40-1=39$, dari Tabel $\mathrm{t}$ didapatkan nilai ttabel $=2,002$. Uji $\mathrm{t}$ dari pengaruh variabel kinerja tutor $(\mathrm{X})$ terhadap variabel kepuasan mahasiswa (Y). Berdasarkan analisis diperoleh bahwa $t_{\text {hitung }}=6,952$ yang berarti $t_{\text {hitung }}$ lebih besar dari $t_{\text {tabel }}$ dan nilai signifikansi sebesar 0,000 atau $0 \%$ yang berarti lebih kecil dari nilai $\alpha$ yaitu $5 \%$, artinya $\mathrm{H} 0$ ditolak dan $\mathrm{H} 1$ diterima. Hal ini menunjukkan bahwa kinerja tutorial berpengaruh signifikan positif terhadap kepuasan mahasiwa. Dari uraian di atas maka dapat diketahui tidak semua variabel bebas (kinerja tutor) memiliki pengaruh yang signifikan terhadap variabel terikat (kepuasan mahasiswa).

\section{KESIMPULAN DAN SARAN Kesimpulan}

Berdasarkan hasil dan pembahasan penelitian yang telah dilakanakan diambil kesimpulan sebagai berikut :

1. Hasil analisis deskriptif dari ketujuh indikator yang dianalisis diperoleh jumlah persentase skor aktual jawaban responden secara rata-rata sebesar 77,11 persen. Berdasarkan kriteria pemberian skor nilai tersebut berada pada kategori baik,

2. Hasil analisis regresi linear sederhana menunjukkan persamaan $\dot{\mathrm{Y}}=0,211+$ $0,144 \mathrm{X}$, yang berarti nilai konstanta sebesar 0,211 adalah besar/tingginya kegiatan tutor melalui tutorial webinar yang dilaksanakan tanpa memperhatikan tinggi rendahnya kepuasan mahasiswa. Sedangkan nilai koefisien regresi sebesar $0,144 \mathrm{X}$ yang berarti setiap terjadi peningkatan kegiatan tutor melalui tutorial webinar sebesar 1 kegiatan, maka akan terjadi peningkatan kepuasan mahasiswa sebesar 0,144.

3. Nilai Koefisien Determinasi atau $\mathrm{R}^{2}$ sebesar 0.598 atau $59,8 \%$ yang artinya pengaruh kinerja tutor terhadap kepuasan mahasiswa pada tutorial webinar (Tuweb) adalah sebesar $59,8 \%$. Sedangkan sisanya $40,2 \%$ dipengaruhi faktor lain yang tidak dibahas dalam penelitian ini.. 
4. Hasil uji-t menunjukkan bahwa nilai signifikan lebih kecil dari nilai alpha, dimana nilai signifikan $=0,018<$ alpha $=$ 0,05 yang berarti bahwa signifikan, sehingga hipotesis yang diajukan yakni: "diduga bahwa kinerja tutor berpengaruh signifikan terhadap kepuasan mahasiswa dinyatakan " diterima".

5. Hasil penelitian menunjukkan, UT perlu terus meningkatkan kinerja tutorial online karena berpengaruh secara signifikan terhadap kepuasan mahasiswa. Hal ini sangat mendukung dengan kondisi pembelajaran di masa pandemic Covid-19 ini yang sangat mengharuskan semua sector dan bidang terutama dalam bidang pendidikan yang menuntut untuk terus berinovasi untuk menggalakkan system pembelajaran daring atau online.

\section{Saran}

Ada pun dari hasil penelitian yag dapat di sarankan untuk dapat dilakukan UT ke depan berdasarkan temuan penelitian ini antara lain:

1. Ketepatan waktu pengumuman hasil UAS dan penilaian yang valid, dimana hal ini terkait dengan efektifitas dan efisiensi pelayanan pusat pengujian.

2. Selain itu dalam hal layanan mahasiswa, ke depannya UT perlu lebih meningkatkan akses kemudahan mahasiswa mendapatkan informasi secara online cara melalui efektifitas dan efisiensi teknologi UT (internet, SLI UT, e-mail, dan lain-lain). Langkah perbaikan untuk peningkatan kepuasan mahasiswa juga dapat dilakukan dengan cara tutor aktif memberikan umpan balik yang efektif terhadap proses belajar mahasiswa.

3. Dari metode pembelajaran, hal-hal yang perlu diperbaiki adalah mendorong dan memotivasi mahasiswa dalam belajar mandiri dengan kombinasi cara belajar yang efektif baik melalui Tuweb atau TTM.

4. UT juga harus terus meningkatkan kualitas layanan mahasiswa seperti keefektifan dalam berkomunikasi, pelayananan registrasi, kecepatan respon/penanganan terhadap pertanyaan/ pengaduan dan penyelesaian masalah mahasiswa dengan baik, kepedulian petugas/staf UT, akses terhadap teknologi informasi UT, dan efisiensi pelayanan mahasiswa.

\section{DAFTAR RUJUKAN}

Arifin A, (2004). Kinerja guru pembimbing sekolah menengah umum. Disertasi doktor, tidak diterbitkan. Universitas Negeri Jakarta.

Bahri, S. dan Aswan Z, 2006. Strategi Belajar Mengajar. Edisi. Revisi, Cetakan. III, Jakarta. Rineka Cipta

Buchori Achmad (2012) Pengembangan asessment geometri online berbasis proprofs di perguruan tinggi jurnal aksioma IKIP PGRI Semarang

Djaali, et.all. (2000). Pengukuran Dalam Pendidikan. Program Pascasarjana, Jakarta.

Hanover Research. (2011). Innovative Practicess for Improving Students Performance in College Mathematics.

www.mybrcc.edu/intranet/attachments/art icle/110/Innovative_Practices_for-

Improving_StudentPerformance_in_Colle ge_Level_Mathematics.pdf (Retrieved March 1st 2014)

Hendrick III, George Harrison, (2012). Preditors of Success for Community College Developmental Mathematics Students in Online, Hybrid, and Traditional Courses, A Dissertation. edl.appstate.edu/sites/ edl.appstate.edu/ files/Hendricks_George_Dissertation.pdf (Retrieved March 1st 2014).

Herawati. (2012). Analisis Pola Interaksi Mahasiswa pada Tutorial Online Pendidikan Fisika. Repositori SIMPEN UT

Mangkunegara, Anwar Prabu. (2004). Manajemen Sumber Daya Manusia Perusahaan. Bandung: PT Remaja Rosdakarya

Muhtar, (2003). Merambah Manajemen Baru: Pendidikan Tinggi Islam. Jakarta: CV. Misaka Galiza

Pradinansyah, Arvan, (1999), Peranan Kepemimpinan dalam membangun Kepercayaan di tempat Kerja , Dalam Manajemen dan Usahawan Indonesia, September 1999.

Ramli, A., Rahmatullah, R., Inanna, I., \& Dangnga, T. (2018). Peran Media Dalam Meningkatkan Efektivitas Belajar. Lembaga Pengabdian Kepada Masyarakat Universitas Negeri Makassar, 5-7.

Robbin, Stepen P, (2014), Perilaku Organisasi : Konsep, kontraversi dan Aplikasi, terjemahan Hadyana Pujuaatmaka, Cetakan ke tujuh, Prenhalindo, Jakarta. 
Sarwoto, (2008), Manajemen, Ghalia Indonesia, Jakarta.

Sil, Muhamad dan Johan Sapri, (2008), Kelembagaan Pendayagunaan Staf dan Beban Kerja Unit Kerja pada UPBJJ-UT Provinsi Bengkulu, laporan penelitian, tidak Publikasikan, LPPM-UT, Jakarta.

Sopiatin, Popi, (2010). Manajemen Belajar Berbasis Kepuasan Siswa, Bogor: Ghalia Indonesia

Subandijo, (1991), Persepsi Lulusan tentang Sistem Pendidikan Jarak Jauh, Buletin UT , Edisi Januari, Karunika.

Sudjana, N. (2002) . Dasar-Dasar Proses Belajar Mengajar. Bandung: Sinar Baru Algensido Offset.

Supardi. (2003). Kinerja Karyawan. Ghalia Jakarta

Suparman, Atwi, (2004), Universitas Terbuka Memasuki Era Gelora Simintas tahun 2004 disampaikan kepada Civitas Akademika UT sebagai bahan Penyegaran dan Pencerahan dalam Memantapkan Masa Depan UT, Pondok Cabe, Jakarta.

Suparman, Atwi dan Aminudin Zuhairi, (2004), Pendidikan Jarak Jauh : Teori dan Praktek, Pusat Penerbitan Universitas Terbuka, Jakarta.

Sukardi. (2007). Metodologi Penelitian Pendidikan Kompetensi dan Praktiknya. Jakarta: Bumi Aksara.

Thoha, Miftah, (2012), Perilaku organisasi : Konsep dasar dan Aplikasi, Cetakan ke duabelas, Raja Grafindo Persada, Jakarta.

Tjiptono, F. (2002), Strategi Pemasaran, Yogyakarta : Andi Offset.

Tim Semintas , (2007), Petunjuk Kerja Pelaksanaan Ujian Akhir Semester Universitas Terbuka, Semintas UT, Jakarta.

Wardani, I.G.K. (2000). Program Tutorial Dalam Sistem Pendidikan Tinggi Terbuka dan Jarak Jauh. Jurnal Pendidikan Terbuka Jarak Jauh. Volume 1, nomor 2, September. Universitas Terbuka, (2016), Panduan Penelitian tahun 2016-2020, LPPM-UT, Jakarta. 